IN FOLIO 



\title{
Insistir y resistir: la denuncia poética comunitaria frente a la violencia nacional
}

\author{
Por Dámaso Andrés Rabanal Gatica ${ }^{1}$ \\ Pontificia Universidad Católica de Chile - CONICYT
}

\begin{abstract}
Sol, Daniela. (Comp.). (2017). Verbo latente. Antología de poesía social reciente. Talca: Helena Editorial, 127 p.
\end{abstract}

\section{La necesidad de legitimar los Derechos Humanos}

Una jueza dela república pierde la tuición de sus hijas por visibilizar su orientación sexual lésbica. Sin este juicio internacional en Chile no se estaría avanzando en diferentes acciones por los Derechos Humanos y la no discriminación. Un joven es asesinado en la calle. Es de noche. Quebraron sus extremidades y cortaron su piel diseñando una esvástica sobre el pecho, para luego dejarlo abandonado. Hoy existen memoriales y una Ley Antidiscriminación reactiva. Siempre reactiva, como es costumbre en Chile, dejando lejos toda iniciativa política y acordada por la prevención

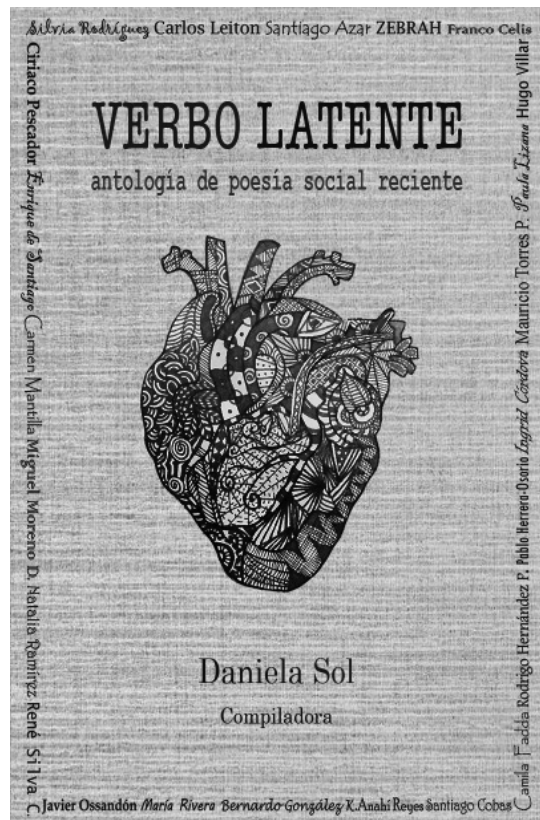
y la educación. Un joven se suicida tras ser acusado en su colegio por portar marihuana. Una mujer haitiana, Joane Florvil, muere en medio de la negligencia institucional. El racismo es evidente, y parafraseando a María Emilia Tijoux, en Racismo en Chile. La piel

\footnotetext{
${ }^{1}$ Doctor (C) en Literatura-Becario CONICYT- y Magíster en Letras con mención en Literatura por la Pontificia Universidad Católica de Chile. Licenciado en Educación, profesor de Castellano y Comunicación, y Magíster en Didáctica de la Lengua Materna por la Universidad del Bío-Bío. Diplomado en Estudios de Género por la Universidad de Chile. Sus intereses investigativos están relacionados con el estudio de la cultura a través de la educación, la literatura, el género y los derechos humanos. e-mail: damrab31@gmail.com
} 
como marca de la inmigración (2016), los patrones de segregación vienen coloreados por la piel. Dos mujeres fueron asesinadas en Chillán este año nuevo. Aumenta la tasa de feminicidios. Todos los años, miles de profesores/as, que deberían avanzar hacia el contrato indefinido, son despedidos, armando un circuito de rotación infinito que sustenta la precariedad de muchos contextos laborales.

Esta no es la crónica roja de un día o de un periódico en particular; tampoco son todos los sucesos. Son diferentes momentos, distintas memorias, en las que se evidencian profundas huellas y zonas de dolor que nos acompañan desde el nacimiento hasta la muerte en un Chile fanático y adulador de la violencia como mecanismo de resolución de conflictos y legitimadora de poderes.

En Chile una de las mayores manifestaciones de la operación biopolítica -considerado lo biopolítico desde Foucault, Giorgi y Espósito- responde a transformar el cuerpo en un instrumento, dominarlo y quitarle la humanidad: un engranaje del modelo capitalista donde todo se compra, donde el cuerpo se negocia y no hay espacios para saber quién se es y mucho menos por saber quién es el/la otro/a. Estamos alienados, encriptados, categorizados y mediados por el mercado en sus múltiples formas siempre violentas. No olvidemos que en nuestro país se ha vendido mayoritariamente todo, incluso el agua, y eso no lo trae de regreso la fantasía crediticia ni el trabajo esforzado, porque todo atisbo de bienestar se paga en la Aseguradora de Fondos de Pensiones (AFP); en las "oportunidades" de consumo adquiridas de manera emergente en instituciones de banca privada; en jubilaciones miserables; en diseños de vejez penosos. En este Chile doloroso, el sujeto es útil mientras trabaja, es productivo, y cuando deja de hacerlo pareciera que debe morir.

Es así como la concepción de lo "social" se ha vuelto eslogan en su vía colectiva desde el discurso cotidiano, para resignificar(se) en una peligrosa apropiación que anestesia la consistencia política del concepto, anula la colectividad que vive simbólicamente en el significante para hacerlo moda, siendo la cultura -una vez más- la frontera desde la cual inquietar para detener esa naturalización agresiva y blanqueada de un signo -lo social- que, por sobre todas las cosas, significa comunidad. En este último caso se ubica la publicación del libro que reseñamos.

Verbo Latente. Antología de poesía social reciente (2017), compilado por la poeta, académica e investigadora Daniela Sol (1983) y editado por Helena Editores, además de diseñado por Isis Iturriaga (Ciudad de México) e ilustrado por Javiera Soto (Talca, Chile), es una antología 
de poesía social que recoge el trabajo artístico de 24 escritores que tensionan los diseños socioculturales nacionales hegemónicos, preguntándose por la (in)justicia social, la distribución de la riqueza, la desigualdad, el racismo, la violencia de género, la explotación laboral, la discriminación, la invisibilidad de los derechos humanos dentro de la consciencia ciudadana individual y muchas veces colectiva, los sujetxs minorizadxs y la diversidad cultural, entre otros temas. En palabras de Daniela Sol: "Crear esta antología surge de la necesidad de visibilizar ciertas problemáticas que como agentes sociales experimentamos, nos producen indignación, arcadas o silencio" (7: 2017)

\section{El origen, el territorio y la crítica poética.}

Verbo Latente aparece en el campo artístico de la Región del Maule, Chile, para construir una memoria poética de la escritura comprometida nacional que aconteció durante el siglo XX, un puente creativo que mira distintos orígenes y diferentes experiencias y capitales culturales desde los/las escritores/as que participan en el libro. Es así como con esta iniciativa literaria y cultural es posible rememorar las imágenes descritas en algunas elocuentes palabras de Pablo de Rokha, o las aventuras creativas y críticas de La Mandrágora, o la voz intensa de un Pablo Neruda más militante que escribía para enunciar amores hacia una colectividad empoderada; las preocupaciones de Carlos Droguett en Sesenta muertos en la escalera (1953), o las de Manuel Rojas con su Hijo de ladrón (1951) para enunciar la injusticia, inequidad y diferencias sociales; en diferentes lenguajes, incluso; y hace menos tiempo, Juan Radrigán nos decía en el teatro que los Hechos Consumados, o las penurias de El loco y la triste, o las angustias de los Testimonios de las muertes de sabina (1998) acontecieron y siguen sucediendo más allá del radical tránsito entre dictaduras del siglo XX.

Estas preocupaciones $\mathrm{y}$ atenciones fueron posteriormente performadas a través del lenguaje en los libros de crónicas $L a$ esquina es mi corazón (1997) o Zanjón de la aguada (2003), de Pedro Lemebel, así como también en las novelas Lumpérica (1983) y Fuerzas Especiales (2013), de Diamela Eltit, y más recientemente por la escritura generosa y valiente de Nona Fernández, en sus novelas Mapocho (2006), Av. 10 de julio Huamachuco (2007) o Fuenzalida (2012). Incluso Marisol García, desde el periodismo de investigación, en su libro Canción Valiente (2013), nos permite pensar en una trayectoria de la cultura comprometida a través de la música, considerando desde Quilapayún y su Cantata de Santa María 
de Iquique o los tremendos Violeta Parra y Víctor Jara, cancioneros enérgicos en colectividad y compromiso con el cuerpo social, político y comunitario, que hoy en día es nuevamente cantado y actualizado en las producciones musicales de Evelyn Cornejo, Manuel García, Chinoy, Kaskivano, o el rap de Ana Tijoux, Cévlade, Portavoz, GranRah, Cómo asesinar a Felipes, entre otros.

En este breve panorama de lo que podríamos considerar una "escritura o voces comprometidas", entendiendo que todo proceso de escritura se compromete con algo/alguien, esta antología de poesía social compilada, o más bien dicho, urdida y tejida por Daniela Sol, vuelve a dinamizar estas preguntas por la situación del nos-otros dentro del diseño social contemporáneo, activando las colectividades y discursos poéticos para preguntarse, poética y políticamente, por Chile, sus orígenes, situación y horizontes.

Entre los mayores desafíos de esta iniciativa literaria se encuentra el diseño de la comunidad creativa y el posicionamiento de las diferentes voces alimentando el llamado de la poesía social. Formar un entramado temático, que además tiene asidero en situaciones materiales de lo cotidiano, genera un espacio de responsabilidad significativo donde el lenguaje se construye en y con el otro mediante una voz poética que tensiona y complejiza las discusiones teóricas relativas a quiénes pueden hablar por otros, asumiendo que siempre se es un otro con más o menos privilegios en un contexto social.

Si bien al pensar en poesía social pareciera que se elabora un territorio de convivencia en el que todos estamos involucrados de alguna manera, en el entendido rizomático y articulado de los diseños sociales, es posible decir que en Verbo Latente coexisten diversos lugares de enunciación posibles de articular en dos grupos: "Los que hablan de otros" y "Los que hablan de su propia alteridad", formulando un diálogo textual significativo y desafiante para quienes diseñan el libro y fundamentalmente para sus lectores.

\section{Aún queda mucho por escribir}

Esta antología de poesía social se posiciona como una acción poética y política que permite comprender, dialogar y problematizar la conformación del lugar de las literaturas regionales en el panorama cultural y centralista de la sociedad chilena posdictatorial. Un librocomunidad que enuncia desde su territorio; un libro-telar que diseña patrones analíticos y artísticos de denuncia y resistencia poética; un quipu literario comprometido y participante de un diseño social que 
se pregunta insistentemente por el lugar de la cultura/literatura, considerando sus influencias materiales -efectivas y posiblessobre los espacios culturales, así como también la instalación de un discurso literario crítico sobre el cual escritores y lectores puedan interactuar y proponer vías creativas alternativas que fracturen las representaciones e imaginarios sociales y nacionales anquilosados por el tiempo, sobre todo en un contexto regional. Es así como el libro Verbo latente es una acción en sí misma que se moviliza, que habla, que propone, que discute. Porque la cultura y la comunidad son, fueron y siguen siendo la real forma de resistencia. 
